\title{
High percentages of embryos with 21,18 or 13 trisomy are related to advanced paternal age in donor egg cycles
}

\author{
Javier García-Ferreyra ${ }^{1,3}$, Roly Hilario², Julio Dueñas ${ }^{1,2}$ \\ ${ }^{1}$ FERTILAB Laboratory of Assisted Reproduction, Lima, Peru \\ 2PROCREAR Fertility Center, Lima, Peru \\ ${ }^{3}$ Laboratory of Assisted Reproduction. Alcívar Hospital, Guayaquil, Ecuador
}

\begin{abstract}
Objective: Advanced paternal age is related to poor sperm quality; however, little is known on its effect on aneuploidy embryo rates and, more importantly, on chromosomal abnormalities like trisomy 21,18 and 13 . The objective of this study was to evaluate the effect of advanced paternal age on the trisomy rates of the chromosomes 21, 18 or 13 in embryos obtained from donated oocytes.

Methods: A total of 378 embryos, obtained from 52 IVF/ICSI cycles with donated oocytes in conjunction with PGD, were allocated according to paternal age in three groups: Group A: $\leq 39$ years ( $n=115$ embryos), Group B: 40-49 years ( $n=157$ embryos) and Group C: $\geq 50$ year ( $n=106$ embryos). Fertilization rates, embryo quality at day 3 , blastocysts development, and aneuploidy embryo rates were then compared.

Results: There was no difference in seminal parameters (volume, concentration and motility) in the studied groups. Fertilization rate, percentages of zygotes that underwent cleavage, and good-quality embryos on Day 3 were similar between the three groups evaluated. The group of men $\geq 50$ years had significantly more sperm with damaged DNA, higher global aneuploidy rates, and significantly more embryos with trisomy 21,18 or 13 compared to the other two evaluated groups $(p<0.05)$.

Conclusion: Our data shows that advanced paternal age increases global chromosomal abnormalities, and percentages of trisomy 21,18 or 13 in embryos, and such effect is significantly important as of the age of 50 . Embryo genetic screening is highly recommended in patients in which paternal age is $\geq 50$ years old.
\end{abstract}

Keywords: aging, oocyte, aneuploidy, trisomy, PGD, ART

\section{INTRODUCTION}

Assisted reproduction technologies (ART) enable treating most infertile couples in the world. Achieving satisfactory pregnancy and implantation rates, and the noninvasive selection of embryos free of chromosomal abnormalities is the main challenge in this human reproductive field. Aneuploidies are common in early human embryos (Munné \& Cohen, 1998), and the most important contributor to poor outcomes in IVF. Their frequency in human preimplantation embryos generated during IVF is estimated to be between $56-84 \%$ (Fragouli et al., 2014), and their occurrence is related to maternal and paternal factors. Most aneuploidies are incompatible with life and result in non-viable embryos, manifested as developmental arrest prior to implantation, miscarriage or stillbirth. However, depending on the chromosome involved, some aneuploidies can be viable, such as trisomy 21 (Down syndrome), trisomy 18 (Edwards syndrome) and trisomy 13 (Patau syndrome).

Down syndrome or trisomy 21, described in 1866 by John Langdon Down, is the most common neurodevelopmental disorder with a known genetic cause. It has a birth prevalence of 1:700-1:1000 live births (Savage et al., 1998), and its risk increases exponentially with increasing maternal age (Weijerman \& de Winter, 2010; Oster-Granite et al., 2011). Approximately $95 \%$ of trisomy 21 babies happen by a maternal nondisjunction during the meiotic division, a $4 \%$ are due to a parental balanced robertsonian translocation between chromosomes 13 or 14 and 21; and $1 \%$ are caused by postzygotic mitotic nondisjunction (Gilbert-Barness, 2007). Trisomy 18, described by John Hilton Edwards in 1960, occurs in $1 / 7000$ births (Goldstein \& Nielsen, 1988), has a high percentage of prenatal fetal loss, and postnatally $60 \%$ of cases die within 2 months and more than $95 \%$ within a year. Most trisomy 18 cases are due to a maternal meiotic nondisjunction, with only $5 \%$ being caused by a parental balanced reciprocal translocation (Witters et al., 2011). Finally, trisomy 13, discovered by Klaus Patau in 1960, has an incidence of $1 / 19,000$ live births (Goldstein \& Nielsen, 1988), fetal loss around $97 \%$ and, in the postnatal period, nearly all trisomy newborns die within 4 months. The common cause of trisomy 13 is maternal meiotic nondisjunction (Witters et al., 2011).

García-Ferreyra et al. (2015) evaluated the effects of male aging on aneuploidy rates in embryos obtained from donated oocytes, and reported that men $\geq 50$ years significantly produced more aneuploidy embryos, and this event was related to high percentages of sperm DNA fragmentation. Moreover, regarding this association between advanced paternal age and risk of trisomy 21,18 and 13, the studies are controversial. Studies by McIntosh et al. (1995) reported a 2-fold higher risk for trisomy 21 among fathers aged $>50$ years, compared to fathers of 25-29 years, after adjusting for maternal age and other factors. Similar results were also reported by Matsunaga et al. (1978) and Stene et al. (1981). Nevertheless, there is no evidence concerning the effects of advanced paternal age on trisomy 21 (Regal et al., 1980; Hook et al., 1981; Roth et al., 1983; Ferguson-Smith \& Yates, 1984; Hook \& Regal, 1984; Hatch et al., 1990; de Michelena et al., 1993). In relation to trisomy 18 , studies carried out by Ferguson-Smith \& Yates (1984), Hatch et al. (1990) and Naguib et al. (1999) did not show a paternal age effect on Edward's syndrome. Finally, Bugge et al. (2007) reported a greater paternal age in trisomy 13 cases with paternal meiotic origin compared to controls, but Hatch et al. (1990) did not find an association between male aging and trisomy 13 in spontaneous abortions.

On the other hand, oocyte donation in which the effect of maternal age on oocyte and subsequent embryo is controlled provides an optimal model to study the influence of male aging on embryo quality and its implantation rate (Wong et al., 1996). Several studies have used this model obtaining high pregnancy rates and good obstetrical outcomes in recipients (Sauer \& Kavic, 2006; Budak et al., 2007). Regarding chromosome abnormalities in embryos of egg donors, several studies reveal percentages of aneuploidy embryos to be between $39-82 \%$ (Reis Soares et al., 2003; Munné et al., 2006; Sills et al., 2014; García-Ferrey- 
ra et al., 2015; Haddad et al., 2015; Munné et al., 2017), and only García-Ferreyra et al. (2015) evaluated the effects of paternal age on the aneuploidy.

The objective of this study was to evaluate the effects of advanced paternal age on the trisomy rates of the chromosomes 21, 18 and 13 in embryos obtained from donated oocytes.

\section{MATERIALS AND METHODS}

\section{Study design}

This is a retrospective nonrandomized study based on data analysis from 363 embryos, which were obtained from 50 IVF/ICSI donor egg cycles in conjunction with PGD (IVF: $n=30$; ICSI: $n=22$ ). In our center, all patients (including recipient of donated oocytes) are offered aneuploidy screening as a means to increase pregnancy rates, decrease loss rates, and avoid children with serious medical problems (e.g., Down syndrome). The procedures were done at FERTILAB Laboratory of Assisted Reproduction (Lima, Peru) between January 2012 and July 2016. Written informed consents were obtained from all recipients and their partners included in this study to share the outcomes of their cycles for research purposes. This study was approved by the Institutional Review Board and the corresponding Ethics Committee from Clínica Oncogyn (Lima, Peru).

Thirty-four anonymous oocyte donors (20-30 years old) underwent physical, gynecological and psychological examinations and there were no family histories of hereditary or chromosomal diseases. All participants had a normal karyotype and tested negative for sexually transmitted diseases. Oocyte donor Recruitment was done based on recommendations provided by other donors, and the donation of their gametes was merely for altruistic reasons.

\section{tion}

Controlled ovarian stimulation and oocyte collec-

The menstrual cycles of oocytes donors were stimulated using recombinant FSH (rFSH) (Gonal ${ }^{\circledR}$, Merck Serono laboratories, Peru) according to previously established stimulation protocols (Tavmergen et al., 2002). Medication was started on day 2 of the menstrual cycle until at least three follicles reached $\sim 18 \mathrm{~mm}$ in diameter. The oocytes were collected $36 \mathrm{~h}$ after $\mathrm{hCG}$ administration (Pregnyl ${ }^{\circledR}$, Ferring Farmaceutical, Peru) by transvaginal ultrasound ovum pick-up. During the follicular aspiration procedure, the oocytes were recovered in Global ${ }^{\circledR}$-HEPES-buffered medium (LifeGlobal) supplemented with $10 \%$ vol/vol Serum Substitute Supplement (SSS; Irvine Scientific). After retrieval, cumulus-oocyte complexes were trimmed of excess cumulus cells using sterile needles and cultured in $\sim 200 \mu \mathrm{L}$ drops of Global $^{\circledR}$-Fertilization medium (LifeGlobal) plus $10 \%$ SSS under oil at $37^{\circ} \mathrm{C}$ and room air containing $6 \% \mathrm{CO}_{2}, 5 \% \mathrm{O}_{2}$ and $89 \% \mathrm{~N}_{2}$ for 5 hours before the IVF/ ICSI procedure.

\section{Insemination, fertilization and embryo culture}

The recovered oocytes were assessed for their nuclear maturity, and only metaphase II oocytes were submitted to IVF/ICSI. Insemination was made with 50,000-100,000 motile spermatozoa in $\sim 200 \mu \mathrm{L}$ drops of $\mathrm{Global}^{\circledR}$-Fertilization medium $+10 \%$ SSS, where 1 to 5 oocytes were placed. In the ICSI procedures, all collected oocytes were enzymatically denuded off cumulus cells using hyaluronidase (80 IU/mL; LifeGlobal), and injected following routine procedures (García et al., 2007).

Normal fertilization was evaluated 16-18 hours after insemination/injection by the presence of two pronuclei (day 1 ). The zygotes were individually cultured in mineral oil, in 10- $\mu \mathrm{L}$ droplets of Global ${ }^{\circledR}$ medium (LifeGlobal) sup- plemented with $10 \% \mathrm{vol} / \mathrm{vol}$ SSS from day 1 to day 3 , in which the embryos were moved to fresh Global ${ }^{\circledR}$ medium and cultured for 2 days more up to blastocyst stage. On day 3 the embryos were evaluated for cell number, fragmentation and multinucleation and, on day 5, for development to blastocyst and expansion. Good quality day-3 embryos were defined as those with $6-8$ cells and $\leq 10 \%$ of fragmentation. Good quality blastocysts were defined as having an inner cell mass (ICM) and type A or B trophectoderm (Gardner \& Schoolcraft, 1999).

\section{Embryo biopsy, fixation and FISH analysis}

On the third day after insemination, one cell per embryo was biopsied following a protocol described elsewhere (Munné et al., 2003). Individual embryos were placed into calcium/magnesium-free media (PGD Biopsy Medium; LifeGlobal), through a hole on the zona pellucida, opened with Tyrode's acid solution; one nucleated blastomere was removed by aspiration. After biopsies, the embryos were rinsed thoroughly and returned to culture in mineral oil, in $10-\mu \mathrm{L}$ droplets of $\mathrm{Global}^{\circledR}$ medium (LifeGlobal) supplemented with $10 \%$ vol/vol SSS.

Blastomeres were fixed individually following routine protocols to minimize signal overlap and loss of micronuclei (Velilla et al., 2002). PGD analysis was performed by $\mathrm{FISH}$, using probes specific for twelve chromosomes 8,13 , 14, 16, 18, 20, 21, 22 (Abbott Laboratories), X, Y, 15 and 17 (Cellay Inc) following the manufacturer's instructions.

\section{Sperm collection}

Semen samples were collected by masturbation after 3 days of abstinence and on the day of oocyte retrieval. Semen analysis was performed according to World Health Organization criteria (WHO, 2010). After liquefaction, motile spermatozoa were separated from the seminal plasma by centrifugation at $300 \times \mathrm{g}$ for 10 minutes through 1.0 $\mathrm{mL} 95 \%$ and $45 \%$ isolate gradients (Irvine Scientific). The pellet was washed once by centrifugation for $5 \mathrm{~min}$, and was resuspended in $0.1 \mathrm{~mL}$ of Global Fertilization medium $+10 \%$ SSS for IVF/ICSI.

\section{Sperm DNA fragmentation assessment}

Prior to the hormonal stimulation, sperm DNA fragmentation values were evaluated with the Sperm Chromatin Dispersion (SCD) test (Fernández et al., 2003) using the Halosperm ${ }^{\circledR}$ Kit (Halotech DNA, Spain). Operators scored $\geq 500$ spermatozoa for each patient according to the patterns established by Fernández et al. (2003). Sperm nuclei with fragmented DNA produced very small or no halos of dispersed DNA at all, and nuclei without DNA fragmentation released their DNA loops to form large halos.

\section{Statistical Analysis}

The data was statistically analyzed using the $x^{2}$ test and Student's $t$-test as appropriate, and differences were considered to be significant at $p<0.05$. All statistical analysis was carried out using the statistic package Stata 10 (StataCorp, College Station, TX, USA).

\section{RESULTS}

Results of chromosomal status from 378 biopsied embryos were allocated to three groups according to paternal age:

- $\quad \leq 39$ years (range $30-39$ years; $n=16$ )

- 40-49 years (range 40-48 years; $n=22$ )

- $\quad \geq 50$ years (range $50-68$ years; $n=14$ )

There was no difference in oocyte donor age $(24.2 \pm 2.21,24.7 \pm 2.11$ and $24.2 \pm 2.58$ years), days of stimulation $(8.7 \pm 1.05,8.8 \pm 1.08$ and $8.6 \pm 0.94)$ and mean of rFSH treatment $(1295.1 \pm 291.58,1334.6 \pm 250.54$ and 
$1299.1 \pm 93.62 \mathrm{IU} / \mathrm{L}$ ) between the three evaluated groups (data not shown).

Semen characteristics and sperm DNA fragmentation according to male age are shown in Table 1 . Values of semen volume, sperm concentration and progressive motility were similar in the three evaluated groups ( $p=$ not significant). Men $\geq 50$ years old had significantly less spermatozoa with normal morphology, compared to men $\leq 39$ years old $(5.5 \pm 4.70 \%$ versus $9.3 \pm 5.44 \% ; p<0.05)$. Likewise, patients $\geq 50$ years old had significantly high percentages of sperm with fragmented DNA $(33.6 \pm 18.19 \%$ versus $25.6 \pm 15.63 \%$ and $24.1 \pm 14.49 \%$ ) compared to the groups $\leq 39$ years old and $40-49$ years old respectively $(p<0.05)$.

A total of 175, 261 and 155 oocytes were inseminated from $\leq 39$ years, $40-49$ years and $\geq 50$ year's groups, respectively. Fertilization rate (2PN) $(90.9 \%, 83.1 \%$ and $81.3 \%$, percentages of zygotes that underwent cleavage $(98.7 \%, 98.6 \%$ and $96.1 \%)$, mean cell number $(7.3 \pm 1.08$, $7.3 \pm 0.97$ and $7.3 \pm 1.19)$, good-quality embryos on day 3 $(77.7 \%, 78.9 \%$ and $82.6 \%)$, blastocyst formation rate $(47.8 \%, 47.9 \%$ and $42.1 \%)$, and good-quality blastocysts $(88.2 \%, 83.2 \%$ and $81.2 \%)$ were similar from $\leq 39$ years, 40-49 years and $\geq 50$ year's groups, respectively (Table 2 ).

Table 1. Comparison of seminal characteristics according the male age

\begin{tabular}{|l|c|c|c|}
\hline & $\mathbf{5 3 9}$ & $\mathbf{4 0 - 4 9}$ & $\mathbf{2 5 0}$ \\
\hline $\begin{array}{l}\text { Semen } \\
\text { volume (mL) } \\
\text { (Mean } \pm \text { SD) }\end{array}$ & $2.1 \pm 1.19$ & $1.9 \pm 1.31$ & $1.9 \pm 1.10$ \\
\hline $\begin{array}{l}\text { Sperm con- } \\
\text { centration (x } \\
\left.10^{6} / \mathrm{mL}\right)\end{array}$ & $125.4 \pm 46.13$ & $95.4 \pm 43.66$ & $56.8 \pm 50.69$ \\
\hline $\begin{array}{l}\text { Progressive } \\
\text { motility (\%) }\end{array}$ & $30.3 \pm 7.48$ & $28.1 \pm 8.55$ & $25.2 \pm 9.07$ \\
\hline $\begin{array}{l}\text { Sperm } \\
\text { morphology } \\
\text { (\%) }\end{array}$ & $9.3 \pm 5.44$ & $7.4 \pm 3.84$ & $5.5 \pm 4.70 *$ \\
\hline $\begin{array}{l}\text { Sperm DNA } \\
\text { fragmenta- } \\
\text { tion (\%) }\end{array}$ & $25.6 \pm 15.63$ & $24.1 \pm 14.49$ & $33.6 \pm 18.19 * *$ \\
\hline
\end{tabular}

$* p<0.05$ in relation to groups $\leq 39$ years

$* p<0.05$ in relation to groups $\leq 39$ years and $40-49$ years

The characteristics of chromosome abnormalities in the three evaluated groups are summarized in Table 3. Advanced paternal age was significantly associated to high aneuploidy rates in embryos; thus $65.1 \%$ of the embryos from the group of $\geq 50$ years old were aneuploidies compared to $55.6 \%$ in the group of $\leq 39$ years and $53.5 \%$ in the group of $40-49$ years old $(p<0.05)$. Similarly, the prevalence of embryos with trisomy 21,18 or 13 was significantly higher in older men ( $\geq 50$ years old) than that observed in the other evaluated groups (Trisomy $21: 15.1 \%$ versus $6.1 \%$ and $5.7 \%$; Trisomy $18: 14.9 \%$ versus $4.3 \%$ and $3.8 \%$; Trisomy 13 : $14.2 \%$ versus $5.2 \%$ and $2.5 \%$; $p<0.05$ ) (Figure 1 ). From embryos with any trisomy, $50 \%$ (trisomy 21 ), $48.1 \%$ (trisomy 18 ) and $48 \%$ (trisomy 21 ) achieved the blastocyst stage. Additionally, good quality blastocysts were similar in the three trisomy types (Trisomy $21: 80 \%$, trisomy $18: 84.6 \%$, and trisomy $21: 83.3 \%$ ) (Table 4 and Figure 2).
Table 2. Comparison of laboratory results between the three evaluated groups

\begin{tabular}{|l|c|c|c|}
\hline \multicolumn{1}{|c|}{ total } & 193 & $\mathbf{4 0 - 4 9}$ & $\mathbf{2 9 0}$ \\
\hline $\begin{array}{l}\text { No. total } \\
\text { oocytes }\end{array}$ & 175 & 261 & 174 \\
\hline $\begin{array}{l}\text { No. total } \\
\text { inseminated } \\
\text { oocytes }\end{array}$ & $159(90.9)$ & $217(83.1)$ & $126(81.3)$ \\
\hline $\begin{array}{l}\text { No. } \\
\text { fertilized (2PN) } \\
\text { oocytes total } \\
\text { (\%) }\end{array}$ & $157(98.7)$ & $214(98.6)$ & $121(96.1)$ \\
\hline $\begin{array}{l}\text { No. } \\
\text { cleaved oll/ } \\
\text { embryo on Day } \\
\text { 3 (\%) }\end{array}$ & $7.3 \pm 1.08$ & $7.3 \pm 0.97$ & $7.3 \pm 1.19$ \\
\hline $\begin{array}{l}\text { No. } \\
\text { embryo on Day } \\
3 \text { (Mean } \pm \text { SD) }\end{array}$ & 77.7 & 78.9 & 82.6 \\
\hline $\begin{array}{l}\text { Good-quality } \\
\text { embryos on } \\
\text { Day 3 (\%) }\end{array}$ & 87.8 & 47.9 & 42.1 \\
\hline $\begin{array}{l}\text { Blastocyst } \\
\text { formation/2PN } \\
\text { (\%) }\end{array}$ & $\begin{array}{l}\text { Good-quality } \\
\text { blastocysts } \\
\text { (\%) }\end{array}$ & 83.2 & \\
\hline
\end{tabular}

Table 3. Total aneuploidy rate and percentages of embryos with trisomy 21,18 and 13 in men of $\leq 39$ years, $40-49$ years and $\geq 50$ years

\begin{tabular}{|l|c|c|c|}
\hline & $\mathbf{5 3 9}$ & $\mathbf{4 0 - 4 9}$ & $\mathbf{2 5 0}$ \\
\hline $\begin{array}{l}\text { No. total embryos } \\
\text { biopsied/2PN (\%) }\end{array}$ & $\begin{array}{c}115 \\
(72.3)\end{array}$ & $\begin{array}{c}157 \\
(72.4)\end{array}$ & $\begin{array}{c}106 \\
(84.1)\end{array}$ \\
\hline Total aneuploidy rate (\%) & 55.6 & 53.5 & $65.1^{*}$ \\
\hline $\begin{array}{l}\text { Embryos w/trisomy 21 } \\
(\%)\end{array}$ & 6.1 & 5.7 & $15.1^{*}$ \\
\hline $\begin{array}{l}\text { Embryos w/trisomy 18 } \\
(\%)\end{array}$ & 4.3 & 3.8 & $14.9 *$ \\
\hline $\begin{array}{l}\text { Embryos w/trisomy 13 } \\
(\%)\end{array}$ & 5.2 & 2.5 & $14.2^{*}$ \\
\hline
\end{tabular}

$* p<0.05$ in relation to groups $\leq 39$ years and $40-49$ years of age

\section{DISCUSSION}

In the present study, we evaluated the effects of male age on aneuploidy embryo rate and prevalence of trisomy 21,18 , or 13 including only IVF/ICSI cycles using donor oocyte for controlling female age. The data obtained demonstrates a significant negative effect of paternal age beginning from $\geq 50$ years on the aneuploidy, increasing the percentages of embryos with trisomy 21,18 , or 13 . Our results are very important because they directly show that the number of trisomy embryos is higher with paternal aging when the effect of the female age is controlled.

Aneuploidies are the principal cause of implantation failures and miscarriages in human reproduction. Some 


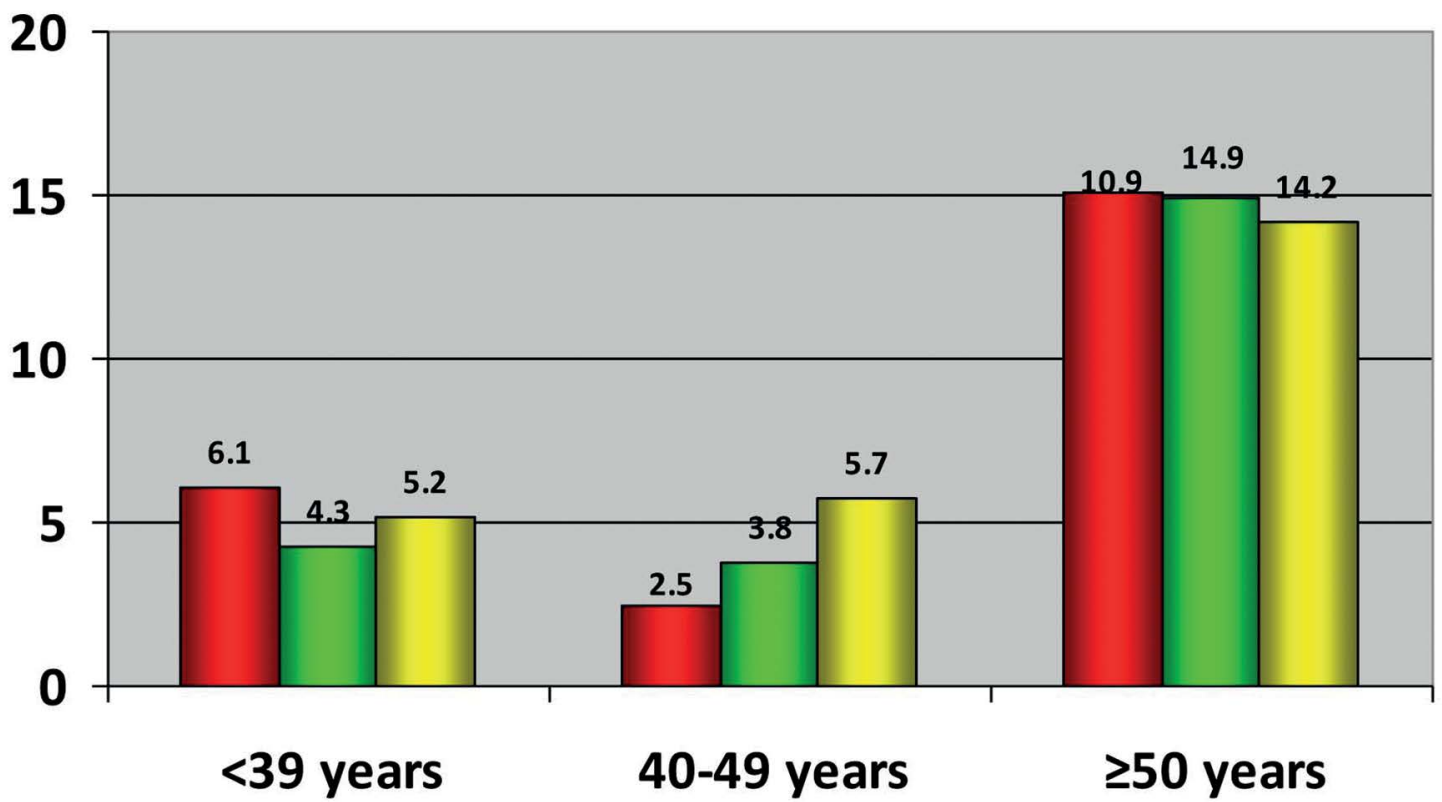

Trisomy $21 \square$ Trisomy $18 \square$ Trisomy 13

Figure 1. Percentage of embryos with trisomy 21,18 and 13 in men of $\leq 39$ years, $40-49$ years and $\geq 50$ years

Table 4. Blastocyst formation rate (BFR) and Good-quality blastocyst (GQB) in embryos with trisomy 21,18 and 13

\begin{tabular}{|l|c|c|c|}
\hline & $\begin{array}{c}\text { Trisomy } \\
\mathbf{2 1}\end{array}$ & $\begin{array}{c}\text { Trisomy } \\
\mathbf{1 8}\end{array}$ & $\begin{array}{c}\text { Trisomy } \\
\mathbf{1 3}\end{array}$ \\
\hline $\begin{array}{l}\text { Blastocyst formation } \\
\text { rate (\%) }\end{array}$ & 50.0 & 48.1 & 48.0 \\
\hline $\begin{array}{l}\text { Good-quality } \\
\text { blastocyst (\%) }\end{array}$ & 80.0 & 84.6 & 83.3 \\
\hline Full blastocyst (\%) & 46.6 & 15.4 & 16.7 \\
\hline Expanded blastocyst (\%) & 26.7 & 23.1 & 25.0 \\
\hline Hatching blastocyst (\%) & 26.7 & 61.5 & 58.3 \\
\hline
\end{tabular}

chromosome anomalies can be compatible with life (trisomy 21,18 and 13), but still produce severe problems in intrauterine and neonatal development, resulting in premature natal death. Down babies have facial dysmorphism with a flattened skull, an enlarged tongue, epicanthal folding, brush field spots (small white spots) in the iris and small low-set ears with a prominent overlapping anti-helix, respiratory disorders, congenital defects of the gastrointestinal tract, endocrine and urinary tract (Roizen \& Patterson, 2003). Trisomy 18 has typical phenotypes, including facial dysmorphism with micrognathia, low set abnormal ears, hirsutism, spina bifida, omphalocele, heart defects, clubfeet, and radial aplasia (Gilbert-Barness, 2007; Witters et al., 2005). Finally, trisomy 13 is characterized by a reduced fetal size for gestational age, central nervous system anomalies, holoprosencephaly, midline facial defects, spina bifida, and urogenital malformations (Gilbert-Barness, 2007; Goetzinger et al., 2008).

There is increasing evidence indicating that advanced paternal age causes several changes in reproductive functions, including decreased circulation of androgens (Kaufman \& Vermeulen, 2005), elevated levels of FSH (Johnson et al., 1990), alteration of testicular morphology (Dakouane et al., 2005), changes in spermatozoa production and characteristics (Kühnert \& Nieschlag, 2004; Hellstrom et al., 2006; Sloter et al., 2006), and a significant increase in spermatic DNA fragmentation in men $>50$ years of age (García-Ferreyra et al., 2012; 2015), similar to the results observed in the present study. These age-related paternal factors may increase the rates of embryonic aneuploidies and lead to miscarriages (de la Rochebrochard \& Thonneau, 2002; Nybo Andersen et al., 2004), congenital birth defects (Olshan et al., 1995; Tellier et al., 1998) lead to the development of several syndromes, such as achondroplasia and Apert (Crow, 2000), neurological disorders (Malaspina et al., 2002), and some cancers (Zhang et al., 1999). It is likely that these abnormalities are due to the inability to repair DNA and/or high levels of meiotic errors (Sartorius \& Nieschlag, 2010).

High percentages of spermatozoa from subfertile and infertile men have damaged DNA; being apoptosis, abnormal chromatin packaging, and reactive oxygen species, the principal molecular mechanisms leading to DNA fragmentation (Sakkas et al., 1999). Several studies have shown that spermatozoa with fragmented DNA are able to fertilize an oocyte, but may result in poor quality embryos, blastocyst development blockage, high aneuploidy rates in embryos, and lower pregnancy and implantation rates in IUI, IVF, or ICSI procedures (Larson et al., 2000; Duran et al., 2002; Henkel et al., 2004; Muriel et al., 2006; García-Ferreyra et al., 2015). Our study reveals an age-dependent increase in sperm DNA fragmentation, which is statistically significant in males $\geq 50$ years old. Similar results were previously reported by Plastira et al. (2007), Vagnini et al. (2007) and García-Ferreyra et al. (2012). Likewise, advanced paternal age was related to high total embryonic aneuploidy rates and embryos with trisomy 21 , 


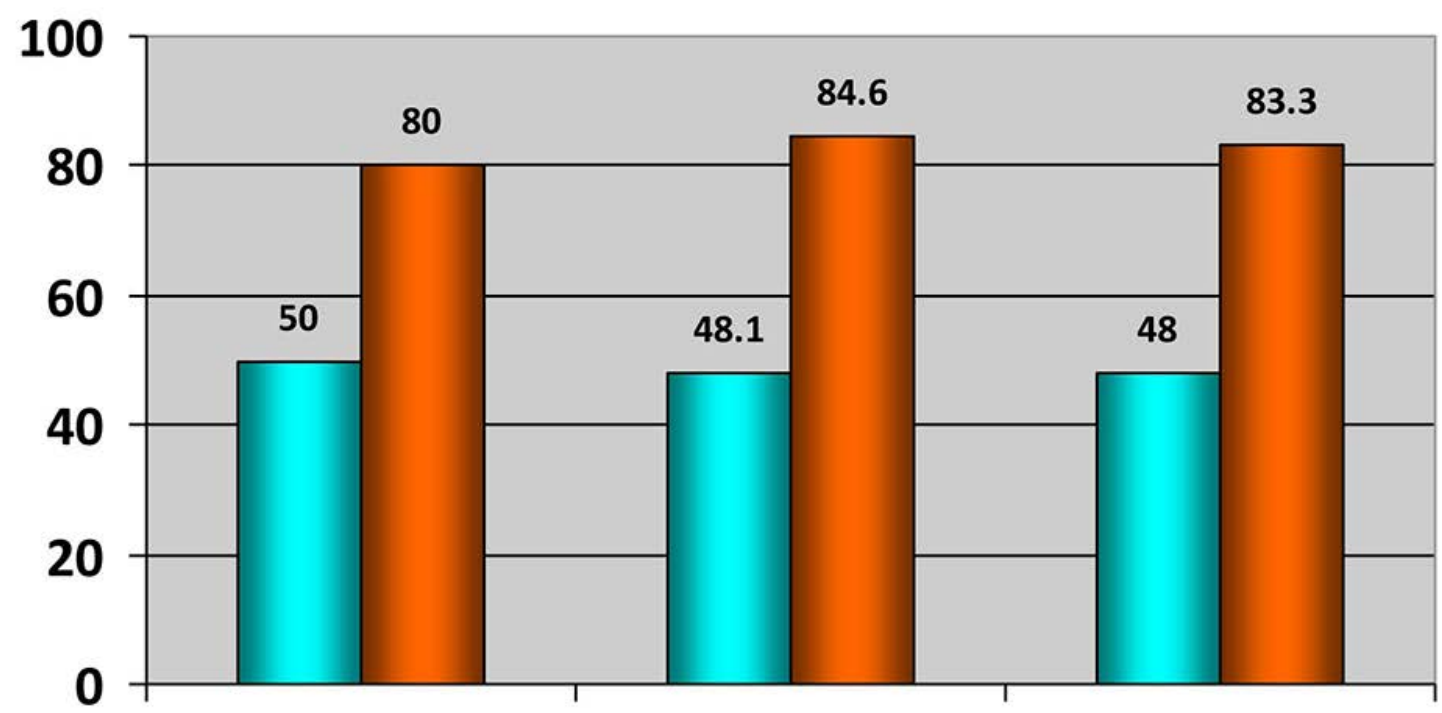

\section{Trisomy $21 \quad$ Trisomy $18 \quad$ Trisomy 13}

\section{Blastocyst formation (\%) $\square$ Good-quality blastocyst (\%)}

Figure 2. Blastocyst formation rate and Good-quality blastocyst in embryos with trisomy 21,18 and 13

18 , or 13 , indicating that it is very important to recommend genetic screening of embryos to patients when the male is over 50 years of age. It has been well documented that advanced paternal age is associated with reduced fertility and higher risks of miscarriage (de la Rochebrochard \& Thonneau, 2002; Kleinhaus et al., 2006), but its effect on the development of trisomy 21,18 and 13 is still controversial. For example, in relation to trisomy 21 , some authors have indicated advanced paternal age to be crucial (Erickson \& Bjerkedal, 1981; Stene et al., 1981; Thepot et al., 1993; McIntosh et al., 1995; Oliver et al., 2009), while others saw no association (Regal et al., 1980; Hook et al., 1981; Roth et al., 1983; Ferguson-Smith \& Yates, 1984; Hook \& Regal, 1984; Hatch et al., 1990; de Michelena et al., 1993). These contradictory observations may be a result of studying trisomy risk in offspring without taking into consideration trisomy embryos that were not implanted or were eliminated early after implantation. Subsequently, a misdiagnosis about the real effect of advance paternal age on chromosomal diseases was carried out.

Most aneuploidies found in embryos originate from the oocyte; however, in the last years several studies have showed an effect of advanced paternal age on aneuploidy rates (Magli et al., 2009; García-Ferreyra et al., 2015), and at least fivefold higher risk of miscarriages (de la Rochebrochard \& Thonneau, 2002). Aneuploidy in embryos can originate by changes in the centrosome that result in abnormal spindle formation and chromosome malsegregation (Palermo et al., 1994), or by the generation of aneuploid gametes during spermatogenesis; and patients with oligoasthenoteratospermia or nonobstructive azoospermia (testicular sperm extracted) with severe defects that may result in higher percentages of mitotic abnormalities and chaotic embryos (Magli et al., 2009). On the other hand, the paternal effect on embryo development can be evaluated after the eight-cell stage when embryo genome activation occurs and thus, paternal genetic information is expressed (late paternal effect) (Tesarik, 2005). This effect causes blastocyst formation failure and low clinical outcomes, and is related to male aging and high percentages of sperm DNA fragmentation (García-Ferreyra et al., 2015). In the present study, there were no differences in fertilization rates, and embryo quality until day 3 in the three age groups, similar to previously reported results (Gallardo et al., 1996; Frattarelli et al., 2008; Ferreira et al., 2010). During culture extended to day 5, a reduction in the blastocyst formation rate in the group of males $\geq 50$ years of age was observed, compared to the other evaluated groups, but this difference was not significant. Furthermore, it is important to highlight that about half of the embryos with some trisomy reached the blastocyst stage, and around $80 \%$ of them were good-quality embryos, which increases the possibility of normal implantation rates and subsequent miscarriage or the birth of a child with genetic disorders. Our findings are very important because they demonstrate that advanced paternal age actively contributes to a higher rate of chromosomal abnormalities in the resulting embryos, and when the type or extent of DNA damage cannot be balanced by the reparative ability of the oocyte (including cases of egg donor), then the genetic screening in embryos should be considered to improve clinical outcomes. Egg donor programs can be considered successful largely because oocyte quality is greatly improved when the donor's age is low and by the absence or minimal chromosomal errors in the oocytes. However, Battaglia et al. (1996) showed that $17 \%$ of human egg collected from healthy women at the age of 22-25 years during natural cycle had spindle abnormalities, which cause aneuploidy in embryos derived from donated oocytes. In the present study, we report a global aneuploidy rate of $57.4 \%$, similar to what was demonstrated by Sills et al. (2014), Haddad et al. (2015) and García-Ferreyra et al. (2015), but this percentage increased to $65.1 \%$ when the male patient was $\geq 50$ years old, suggesting that this event is related to high 
values of sperm DNA fragmentation. On the other hand, advanced paternal age affects the genetic characteristics of embryos, including those obtained from donated oocytes.

In conclusion, our data shows that male aging increases chromosomal abnormalities in the resulting embryos from egg donor, being this effect significant from the age of 50 and older. Genetic screening in embryos should be recommended in egg donor cycles and especially if paternal age is $\geq 50$ years in order to obtain better clinical outcome and reduce the likelihood of abnormal pregnancies, that may end in spontaneous abortions, intrauterine fetal death, intrauterine growth retardation or offspring with several congenital defects.

\section{CONFLICT OF INTERESTS}

Authors disclose no potential conflict of interests.

\author{
Corresponding author: \\ Javier García-Ferreyra \\ FERTILAB Laboratory of Assisted Reproduction \\ Lima, Peru \\ E-mail: jgarciaf@hotmail.com
}

\section{REFERENCES}

Battaglia DE, Goodwin $P$, Klein NA, Soules MR. Influence of maternal age on meiotic spindle assembly in oocytes from naturally cycling women. Hum Reprod. 1996;11:2217-22. PMID: 8943533 DOI: 10.1093/oxfordjournals.humrep.a019080

Budak E, Garrido N, Soares SR, Melo MA, Meseguer M, Pellicer A, Remohí J. Improvements achieved in an oocyte donation program over a 10-year period: sequential increase in implantation and pregnancy rates and decrease in highorder multiple pregnancies. Fertil Steril. 2007;88:342-9. PMID: 17335819 DOI: 10.1016/j.fertnstert.2006.11.118

Bugge $M$, Collins A, Hertz JM, Eiberg $H$, Lundsteen $C$, Brandt CA, Bak M, Hansen C, Delozier CD, Lespinasse J, Tranebjaerg L, Hahnemann JM, Rasmussen K, Bruun-Petersen G, Duprez L, Tommerup N, Petersen MB. Non-disjunction of chromosome 13. Hum Mol Genet. 2007;16:2004-10. PMID: 17584770 DOI: $10.1093 / \mathrm{hmg} / \mathrm{ddm} 148$

Crow JF. The origins, patterns and implications of human spontaneous mutation. Nat Rev Genet. 2000;1:40-7. PMID: 11262873 DOI: $10.1038 / 35049558$

Dakouane M, Bicchieray L, Bergere M, Albert M, Vialard F, Selva J. A histomorphometric and cytogenetic study of testis from men 29-102 years old. Fertil Steril. 2005;83:923-8. PMID: 15820802 DOI: $10.1016 /$ j.fertnstert.2004.12.005

de la Rochebrochard E, Thonneau P. Paternal age and maternal age are risk factors for miscarriage; results of a multicentre European study. Hum Reprod. 2002;17:164956. PMID: 12042293 DOI: 10.1093/humrep/17.6.1649

de Michelena MI, Burstein E, Lama JR, Vásquez JC. Paternal age as a risk factor for Down syndrome. Am J Med Genet. 1993;45:679-82. PMID: 8456845 DOI: 10.1002/ajmg.1320450605
Duran EH, Morshedi M, Taylor S, Oehninger S. Sperm DNA quality predicts intrauterine insemination outcome: a prospective cohort study. Hum Reprod. 2002;17:3122-8. PMID: 12456611 DOI: 10.1093/humrep/17.12.3122

Erickson JD, Bjerkedal TO. Down syndrome associated with father's age in Norway. J Med Genet. 1981;18:22-8. PMID: 6454784 DOI: $10.1136 / j m g .18 .1 .22$

Ferguson-Smith MA, Yates JR. Maternal age specific rates for chromosome aberrations and factors influencing them: report of a collaborative european study on 52 965 amniocenteses. Prenat Diagn. 1984;4:5-44. PMID: 6235485 DOI: $10.1002 / p d .1970040704$

Fernández JL, Muriel L, Rivero MT, Goyanes V, Vazquez $\mathrm{R}$, Alvarez JG. The sperm chromatin dispersion test: a simple method for the determination of sperm DNA fragmentation. J Androl. 2003;24:59-66. PMID: 12514084 DOI: $10.1002 / j .1939-4640.2003 . t b 02641 . x$

Ferreira RC, Braga DP, Bonetti TC, Pasqualotto FF, Iaconelli A Jr, Borges E Jr. Negative influence of paternal age on clinical intracytoplasmic sperm injection cycle outcomes in oligozoospermic patients. Fertil Steril. 2010;93:1870-4. PMID: 19409557 DOI: $10.1016 / j$.fertnstert.2008.12.043

Fragouli E, Alfarawati S, Spath K, Wells D. Morphological and cytogenetic assessment of cleavage and blastocyst stage embryos. Mol Hum Reprod. 2014;20:117-26. PMID: 24184690 DOI: $10.1093 / \mathrm{molehr} /$ gat073

Frattarelli JL, Miller KA, Miller BT, Elkind-Hirsch K, Scott RT Jr. Male age negatively impacts embryo development and reproductive outcome in donor oocyte assisted reproductive technology cycles. Fertil Steril. 2008;90:97-103. PMID: 17765235 DOI: $10.1016 /$ j.fertnstert.2007.06.009

Gallardo E, Simón C, Levy M, Guanes PP, Remohí J, Pellicer A. Effect of age on sperm fertility potential: oocyte donation as a model. Fertil Steril. 1996;66:260-4. PMID: 8690113 DOI: $10.1016 / \mathrm{S} 0015-0282(16) 58450-7$

García-Ferreyra J, Romero R, Hilario R, Dueñas-Chacón J. High levels of DNA fragmentation observed in an infertile population attending a fertility center are related to advanced paternal age. J Fertil In Vitro. 2012;2:113. DOI: 10.4172/2165-7491.1000113

García-Ferreyra J, Luna D, Villegas L, Romero R, Zavala P, Hilario R, Dueñas-Chacón J. High Aneuploidy Rates Observed in Embryos Derived from Donated Oocytes are Related to Male Aging and High Percentages of Sperm DNA Fragmentation. Clin Med Insight Reprod Health. 2015; 9:217. PMID: 26604851 DOI: $10.4137 / C M R H . S 32769$

García J, Noriega-Hoces L, Gonzales GF. Sperm chromatin stability and its relationship with fertilization rate after intracytoplasmic sperm injection (ICSI) in an assisted reproduction program. J Assist Reprod Genet. 2007;24:587-93. PMID: 18034300 DOI: $10.1007 /$ s10815-007-9174-1 
Gardner DK, Schoolcraft WB. In vitro culture of human blastocysts. In: Jansen R, Mortimer D, eds. Towards Reproductive Certainly: Infertility and Genetics Beyond; The Plenary Proceedings of the 11th World Congress on In Vitro Fertilization and Human Reproductive Genetics. Pearl River: Parthenon Press; 1999. p. 378-88.

Gilbert-Barness E. Potter's Pathology of the Fetus, Infant and Child. 2nd ed. Philadelphia: Mosby-Elsevier; 2007.

Goetzinger KR, Stamilio DM, Dicke JM, Macones GA, Odibo AO. Evaluating the incidence and likelihood ratios for chromosomal abnormalities in fetuses with common central nervous system malformations. Am J Obstet Gynecol. 2008;199:285.e1-6. PMID: 18771985 DOI: 10.1016/j.ajog.2008.06.100

Goldstein $\mathrm{H}$, Nielsen KG. Rates and survival of individuals with trisomy 13 and 18. Data from a 10-year period in Denmark. Clin Genet. 1988;34:366-72. PMID: 3233784 DOI: $10.1111 /$ j.1399-0004.1988.tb02894.x

Haddad G, Deng M, Wang CT, Witz C, Williams D, Griffith J, Skorupski J, Gill J, Wang WH. Assessment of aneuploidy formation in human blastocysts resulting from donated eggs and the necessity of the embryos for aneuploidy screening. J Assist Reprod Genet. 2015;32:999-1006. PMID: 25956263 DOI: 10.1007/s10815-015-0492-4

Hatch M, Kline J, Levin B, Hutzler M, Warburton D. Paternal age and trisomy among spontaneous abortions. Hum Genet. 1990;85:355-61. PMID: 2394449 DOI: $10.1007 / B F 00206761$

Hellstrom WJ, Overstreet JW, Sikka SC, Denne J, Ahuja S, Hoover AM, Sides GD, Cordell WH, Harrison LM, Whitaker JS. Semen and sperm reference ranges for men 45 years of age and older. J Androl. 2006;27:421-8. PMID: 16452528 DOI: $10.2164 /$ jandrol.05156

Henkel $R$, Hajimohammad $M$, Stalf $T$, Hoogendijk $C$, Mehnert C, Menkveld R, Gips $H$, Schill WB, Kruger TF. Influence of deoxyribonucleic acid damage on fertilization and pregnancy. Fertil Steril. 2004;81:965-72. PMID: 15066449 DOI: 10.1016/j.fertnstert.2003.09.044

Hook EB, Cross PK, Lamson SH, Regal RR, Baird PA, Uh SH. Paternal age and Down syndrome in British Columbia. Am J Hum Genet. 1981;33:123-8. PMID: 6451171

Hook EB, Regal RR. A search for a paternal-age effect upon cases of $47,+21$ in which the extra chromosome is of paternal origin. Am J Hum Genet. 1984;36:413-21. PMID: 6231859

Johnson L, Grumbles JS, Bagheri A, Petty CS. Increased germ cell degeneration during postprophase of meiosis is related to increased serum follicle-stimulating hormone concentrations and reduced daily sperm production in aged men. Biol Reprod. 1990;42:281-7. PMID: 2110837 DOI: 10.1095/biolreprod42.2.281

Kaufman JM, Vermeulen A. The decline of androgen levels in elderly men and its clinical and therapeutic implications. Endocr Rev. 2005;26:833-76. PMID: 15901667 DOI: 10.1210/er.2004-0013
Kleinhaus K, Perrin M, Friedlander Y, Paltiel O, Malaspina D, Harlap S. Paternal age and spontaneous abortion. Obstet Gynecol. 2006;108:369-77. PMID: 16880308 DOI: 10.1097/01.AOG.0000224606.26514.3a

Kühnert B, Nieschlag E. Reproductive functions of the ageing male. Hum Reprod Update. 2004;10:327-39. PMID: 15192059 DOI: 10.1093/humupd/dmh030

Larson KL, DeJonge CJ, Barnes AM, Jost LK, Evenson DP. Sperm chromatin structure assay parameters as predictors of failed pregnancy following assisted reproductive techniques. Hum Reprod. 2000;15:1717-22. PMID: 10920092 DOI: $10.1093 /$ humrep/15.8.1717

Magli MC, Gianaroli L, Ferraretti AP, Gordts S, Fredericks V, Crippa A. Paternal contribution to aneuploidy in preimplantation embryos. Reprod Biomed Online. 2009;18:536-42. PMID: 19400996 DOI: $10.1016 / S 1472-6483(10) 60131-9$

Malaspina D, Corcoran C, Fahim C, Berman A, HarkavyFriedman J, Yale S, Goetz D, Goetz R, Harlap S, Gorman J. Paternal age and sporadic schizophrenia: evidence for de novo mutations. Am J Med Genet. 2002;114:299-303. PMID: 11920852 DOI: 10.1002/ajmg.1701

Matsunaga E, Tonomura A, Oishi H, Kikuchi Y. Reexamination of paternal age effect in Down's syndrome. Hum Genet. 1978;40:259-68. PMID: 147234 DOI: $10.1007 / B F 00272186$

McIntosh GC, Olshan AF, Baird PA. Paternal age and the risk of birth defects in offspring. Epidemiology. 1995;6:282-8. PMID: 7619937 DOI: 10.1097/00001648-199505000-00016

Munné S, Cohen J. Chromosome abnormalities in human embryos. Hum Reprod Update. 1998;4:842-55. PMID: 10098475 DOI: $10.1093 /$ humupd/4.6.842

Munné S, Sandalinas M, Escudero T, Velilla E, Walmsley R, Sadowy S, Cohen J, Sable D. Improved implantation after preimplantation genetic diagnosis of aneuploidy. Reprod Biomed Online. 2003;7:91-7. PMID: 12930584 DOI: 10.1016/S1472-6483(10)61735-X

Munné S, Ary J, Zouves C, Escudero T, Barnes $\mathrm{F}$, Cinioglu C, Ary B, Cohen J. Wide range of chromosome abnormalities in the embryos of young egg donors. Reprod Biomed Online. 2006;12:340-6. PMID: 16569324 DOI: 10.1016/S1472-6483(10)61007-3

Munné S, Alikani M, Ribustello L, Colls P, Martínez-Ortiz PA, McCulloh DH; Referring Physician Group. Euploidy rates in donor egg cycles significantly differ between fertility centers. Hum Reprod. 2017;32:743-9. PMID: 28333245 DOI: $10.1093 /$ humrep/dex031

Muriel L, Garrido N, Fernández JL, Remohí J, Pellicer $A$, de los Santos MJ, Meseguer M. Value of the sperm deoxyribonucleic acid fragmentation level, as measured by the sperm chromatin dispersion test, in the outcome of in vitro fertilization and intracytoplasmic sperm injection. Fertil Steril. 2006;85:371-83. PMID: 16595214 DOI: 10.1016/j.fertnstert.2005.07.1327 
Naguib KK, Al-Awadi SA, Moussa MA, Bastaki L, Gouda S, Redha MA, Mustafa F, Tayel SM, Abulhassan SA, Murthy DS. Trisomy 18 in Kuwait. Int J Epidemiol. 1999;28:711-6. PMID: 10480700 DOI: 10.1093/ije/28.4.711

Nybo Andersen AM, Hansen KD, Andersen PK, Davey Smith G. Advanced paternal age and risk of fetal death: a cohort study. Am J Epidemiol. 2004;160:1214-22. PMID: 15583374 DOI: $10.1093 / a j e / k w h 332$

Oliver TR, Bhise A, Feingold E, Tinker S, Masse N, Sherman SL. Investigation of factors associated with paternal nondisjunction of chromosome 21. Am J Med Genet A. 2009;149A:1685-90. PMID: 19606484 DOI: 10.1002/ajmg.a.32942

Olshan AF, Ananth $\mathrm{CV}$, Savitz DA. Intrauterine growth retardation as an endpoint in mutation epidemiology: an evaluation based on paternal age. Mutat Res. 1995;344:8994. PMID: 7565898 DOI: $10.1016 / 0165-1218(95) 90043-8$

Oster-Granite ML, Parisi MA, Abbeduto L, Berlin DS, Bodine C, Bynum D, Capone G, Collier E, Hall D, Kaeser $L$, Kaufmann P, Krischer J, Livingston M, McCabe LL, Pace J, Pfenninger K, Rasmussen SA, Reeves RH, Rubinstein Y, Sherman S, Terry SF, Whitten MS, Williams S, McCabe ER, Maddox YT. Down syndrome: national conference on patient registries, research databases, and biobanks. Mol Genet Metab. 2011;104:13-22. PMID: 21835664 DOI: 10.1016/j.ymgme.2011.07.005

Palermo G, Munné S, Cohen J. The human zygote inherits its mitotic potential from the male gamete. Hum Reprod. 1994;9:1220-5. PMID: 7962421 DOI: 10.1093/oxfordjournals.humrep.a138682

Plastira K, Msaouel P, Angelopoulou R, Zanioti K, Plastiras A, Pothos A, Bolaris S, Paparisteidis N, Mantas D. The effects of age on DNA fragmentation, chromatin packaging and conventional semen parameters in spermatozoa of oligoasthenoteratozoospermic patients. J Assist Reprod Genet. 2007;24:437-43. DOI: $10.1007 / \mathrm{s} 10815-007-9162-5$

Regal RR, Cross PK, Lamson SH, Hook EB. A search for evidence for a paternal age effect independent of a maternal age effect in birth certificate reports of Down's syndrome in New York state. Am J Epidemiol. 1980;112:650-5. PMID: 6449148 DOI: 10.1093/oxfordjournals.aje.a113037

Reis Soares S, Rubio C, Rodrigo L, Simón C, Remohí J, Pellicer A. High frequency of chromosomal abnormalities in embryos obtained from oocyte donation cycles. Fertil Steril. 2003;80:656-7. PMID: 12969720 DOI: $10.1016 /$ S0015-0282(03)00787-8

Roizen NJ, Patterson D. Down's syndrome. Lancet. 2003;361:1281-9. PMID: 12699967 DOI: 10.1016/S0140-6736(03)12987-X

Roth MP, Stoll C, Taillemite JL, Girard S, Boué A. Paternal age and Down's syndrome diagnosed prenatally: no association in French data. Prenat Diagn. 1983;3:327-35. PMID: 6228786 DOI: 10.1002/pd.1970030409

Sakkas D, Mariethoz E, Manicardi G, Bizzaro D, Bianchi PG, Bianchi U. Origin of DNA damage in ejaculated human spermatozoa. Rev Reprod. 1999;4:431-7. PMID: 10051100 DOI: $10.1530 /$ ror. 0.0040031
Sartorius GA, Nieschlag E. Paternal age and reproduction. Hum Reprod Update. 2010;16:65-79. PMID: 19696093 DOI: $10.1093 /$ humupd/dmp027

Sauer MV, Kavic SM. Oocyte and embryo donation 2006: reviewing two decades of innovation and controversy. Reprod Biomed Online. 2006;12:153-62. PMID: 16478577 DOI: $10.1016 / S 1472-6483(10) 60855-3$

Savage AR, Petersen MB, Pettay D, Taft L, Allran K, Freeman SB, Karadima G, Avramopoulos D, Torfs C, Mikkelsen M, Hassold TJ, Sherman SL. Elucidating the mechanisms of paternal non-disjunction of chromosome 21 in humans. Hum Mol Genet. 1998;7:1221-7. PMID: 9668162 DOI: $10.1093 / \mathrm{hmg} / 7.8 .1221$

Sills ES, Li X, Frederick JL, Khoury CD, Potter DA. Determining parental origin of embryo aneuploidy: analysis of genetic error observed in 305 embryos derived from anonymous donor oocyte IVF cycles. Mol Cytogenet. 2014;7:68. PMID: 25356087 DOI: $10.1186 / \mathrm{s} 13039-014-0068-5$

Sloter E, Schmid TE, Marchetti F, Eskenazi B, Nath J, Wyrobek AJ. Quantitative effects of male age on sperm motion. Hum Reprod. 2006;21:2868-75. PMID: 16793993 DOI: $10.1093 /$ humrep/del250

Stene J, Stene E, Stengel-Rutkowski S, Murken JD. Paternal age and Down's syndrome: data from prenatal diagnoses (DFG). Hum Genet. 1981;59:119-24. PMID: 6459986 DOI: $10.1007 /$ BF00293059

Tavmergen E, Göker EN, Sendag F, Sendag H, Levi $\mathrm{R}$. Comparison of short and long ovulation induction protocols used in ART applications according to the ovarian response and outcome of pregnancy. Arch Gynecol Obstet. 2002;266:5-11. PMID: 11998967 DOI: $10.1007 /$ PL00007494

Tellier AL, Cormier-Daire V, Abadie V, Amiel J, Sigaudy S, Bonnet $D$, de Lonlay-Debeney $P$, Morrisseau-Durand MP, Hubert $P$, Michel $J L$, Jan D, Dollfus $H$, Baumann $C$, Labrune P, Lacombe D, Philip N, LeMerrer M, Briard ML, Munnich A, Lyonnet S. CHARGE syndrome: report of 47 cases and review. Am J Med Genet. 1998;76:402-9. PMID: 9556299 DOI: 10.1002/(SICI)1096-8628(19980413)76:5<402: :AIDAJMG7>3.0.CO;2-O

Tesarik J. Paternal effects on cell division in the human preimplantation embryo. Reprod Biomed Online. 2005;10:370-5. PMID: 15820045 DOI: $10.1016 / \mathrm{S} 1472-6483(10) 61798-1$

Thepot F, Wack T, Selva J, Czyglik F, Mayaux MJ. Paternal age and pregnancy issues. The CECOS experience. Contracept Fertil Sex. 1993;21:388-90. PMID: 7920925

Vagnini L, Baruffi RL, Mauri AL, Petersen CG, Massaro FC, Pontes A, Oliveira JB, Franco JG Jr. The effects of male age on sperm DNA damage in an infertile population. Reprod Biomed Online. 2007;15:514-9. PMID: 18028741 DOI: $10.1016 / \mathrm{S} 1472-6483(10) 60382-3$

Velilla E, Escudero T, Munné S. Blastomere fixation techniques and risk of misdiagnosis for preimplantation genetic diagnosis of aneuploidy. Reprod Biomed Online. 2002;4:210-7. PMID: 12709269 DOI: $10.1016 / \mathrm{S} 1472-6483(10) 61808-1$ 
Weijerman ME, de Winter JP. Clinical practice. The care of children with Down syndrome. Eur J Pediatr. 2010;169: 144552. PMID: 20632187 DOI: 10.1007/s00431-010-1253-0

Witters I, Claerhout $P$, Fryns JP. Increased nuchal translucency thickness in thrombocytopenia-absent-radius syndrome. Ultrasound Obstet Gynecol. 2005;26:581-2. PMID: 16184503 DOI: 10.1002/uog.1998

Witters G, Van Robays J, Willekes C, Coumans A, Peeters H, Gyselaers W, Fryns JP. Trisomy 13, 18, 21, Triploidy and Turner syndrome: the 5T's. Look at the hands. Facts Views Vis Obgyn. 2011;3:15-21. PMID: 24753843
Wong IL, Legro RS, Lindheim SR, Paulson RJ, Sauer MV. Efficacy of oocytes donated by older women in an oocyte donation programme. Hum Reprod. 1996;11:820-3. PMID: 8671334 DOI: 10.1093/oxfordjournals.humrep.a019260

World Health Organization - WHO. Laboratory manual for examination and processing. 5th ed. Geneva: World Health Organization; 2010.

Zhang $Y$, Kreger BE, Dorgan JF, Cupples LA, Myers RH, Splansky GL, Schatzkin A, Ellison RC. Parental age at child's birth and son's risk of prostate cancer. The Framingham Study. Am J Epidemiol. 1999;150:1208-12. PMID: 10588081 DOI: 10.1093/oxfordjournals.aje.a009947 